\title{
Cneve Tarchunies Rumach
}

\author{
R.ROSS HOLLOWAY \\ Center for Old World Archaeology and Art \\ Brown University
}

\begin{abstract}
RESUMO: O objetivo do Autor neste artigo é realizar um leitura histórica das pinturas da Tumba François em Vulci, detendo-se naquilo que elas podem elucidar a respeito da sequência dos reis romanos do século VI a.C.
\end{abstract}

PALAVRAS CHAVE: Tumba François; realeza romana; pintura mural.

The earliest record in Roman history, if by history we mean the union of names with events, is preserved in the paintings of an Etruscan tomb: the François Tomb at Vulci. The discovery of the François Tomb took place in 1857 . The paintings were subsequently removed from the walls and became part of the Torlonia Collection in Villa Albani where they remain to this day. The decoration of the tomb, like much Etruscan funeral art, draws on Greek heroic mythology. It also included a portrait of the owner, Vel Saties, and beside him the figure of a woman named Tanaquil, presumably his wife (this figure has become almost completely illegible). In view of the group of historical personages among the tomb paintings, this name has decided resonance with better known Tanaquil, in Roman tradition the wife of Tarquinius Priscus.

The historical scene of the tomb consists of five pairs of figures drawn from Etruscan and Roman history. These begin with the scene

(A) Mastarna (Macstrna) freeing Caeles Vibenna (Caile Vipinas) from his bonds (fig.1).

There follow four scenes in three of which an armed figure dispatches an unarmed man with his sword. And here we find:

(B) the armed pair Larth Ulthes (Larth Ulthes) killing Larth Papathnas of Volsinii (?) (Laris Papthnas Velznach),

(C) Rasce (Rasce) slaying Pesna Arcmsnas of Savona (?) (Pesna Arcmsnas Sveamach), and

(D) Aulus Vibenna bringing down Venthi Cau....city uncertain: (Venthi Cau....plsachs),

(E) Marcus Camillus (Marce Camitlnas) about to draw his sword against the crouching Gnaeus Tarquinius of Rome (Cneve Tarchunies Rumach, fig. 2)

The object of this paper is to view what this group of decorations says about the Roman kings of the sixth century B.C. as independent evidence rather than as a gloss on the Roman history as written by the annalists of the second and first centuries B.C. In date the paintings are a full century and more earlier than the earliest annalists, Fabius Pictor and Cincius Alimentius, who were writing in the aftermath of the Second Punic Wars. The decoration of the François 
Tomb, on the other hand, belongs to the second half of the fourth century.

The tomb is composed of a group of small burial rooms, ten in number, entered from larger chambers which follow in sequence down the centerline of the tomb (Plan, fig.3.). The first is the entrance dromos, next a vestibule, both undecorated. They are succeeded by the first painted chamber. It is disposed crossways to the long axis of the tomb. Beginning at the right side of the doorway we find the beginning of the Greek mythological sequence with the scene of Sisyphus and Amphiaraos. As in the case of the major figures in these paintings, both are labeled with inscriptions. Matching these figures on the left of the doorway there is the representation of Ajax and Kassandra. On the short wall of the chamber to the right we find the portrait of Tanaquil and then that of Vel Saties dressed in a toga picta, decorated with two Pyrrhic dancers and a flautist. $\mathrm{He}$ is accompanied by his dwarf Arzna. Matching these figures across the room on the other short wall there are Phoinix and Nestor. Finally on the rear wall of the tomb (which is much abbreviated by the large opening into the inner painted vestibule) there is on the left Eteokles and Polyneikes and on the right the scene of Marcus Camillus and Gnaeus Tarquinius (fig. 2).

The inner vestibule has a large group of figures on each side wall which continue on the short wall at the rear on each side of the doorway leading to the innermost burial chamber. On the left there is the great composition of the sacrifice of the Trojan captives on the tomb of Patroklos. In a symmetrical position on the right we find the series of scenes from Etruscan and Roman history enumerated above.

Many of these scenes satisfied the Etruscan lust for a perpetual flow of blood to cheer the spirits of the dead. Such is the case particularly with the sacrifice of the Trojan captives and the scenes placed opposite to it. It also seems natural to assume that the Etruscan and Roman duels also form a single scene, an episode from Etruscan history in which Mastarna and his companions free Caeles Vibenna and overcome their antagonists who had held him captive. It is possible, however, to view this wall, and the two short returns on which the series of scenes continues, as a succession of unrelated duels, such as the combat of Eteokles and Polyneikes in the first painted chamber. Although the assumption of unity would strenghten the historical conclusions of what follows, it is not necessary to insist on it.

The assault of Marcus Camillus on Gnaeus Tarquinius the Roman confirms the Roman memory of a king named Tarquin. But it does not increase our confidence in the accuracy of early Roman history as it was recounted in the Late Republic.

The representation of his companions in the François Tomb confirms that he is a regal figure. The four victims of the attackers are each identified by the name of their city. Two of them, moreover, wear kingly dress. It is the red stripe on the togas of Larth Papthnas of Volsinii and Pesna Arcmsnas of Savona that identifies the rank of these men. These are togae praetextae and the red stripe on the toga, inherited by the consuls from the kings of Rome, came from the Etruscan kings. Gnaeus Tarquinius of Rome, eventhough the cloth in which he is wrapped is not bordered in red (and it may well not be his toga) must be understood as a king and king of Rome (Bonfante, 1975).

In the annalistic history of Rome put together in the second and first centuries B.C. there is no trace of Gnaeus Tarquinius the King. The various Roman traditions, episodes, and documents, and the material from Greek sources bearing on early Roman history, that were stitched together in the annalistic narrative of early Rome had no trace of him. This fact in itself is a powerful indictment of any theory to the effect that a connected record of regal Rome with entries for each year survived to the time of the late Republic.

The "history" of the first four kings has been exposed by more than one scholar as a fabrication (and definitively so by Poucet, 1985). The first Tarquin, Lucius Tarquinius Priscus, thus stands at the borderline of history and fiction. As a king, he is a shadowy figure. His 
building and engineering achievements are the very same as those attributed to his successor Lucius Tarquinius Superbus. Both are credited with the building of the Cloaca Maxima and the building of the Temple of Jupiter Optimus Maximus. The temple was supposedly paid for from the spoils of Apiolae (Priscus) and Pometia (Superbus), but the two towns are the same; Apiolae, otherwise unknown, simply being Greek for Pometia (Livy, I.37.55, 1; Dion. Hal., III.67-69, Cornell, 1955, p.128-129).Tarquinius Priscus' military campaigns are suspiciously wide ranging and unfailingly victorious. He overcomes Etruscans, Latins and Sabines, conquering places that appear elsewhere on the roll call of Roman triumphs (and at later dates as well) and whose repeated defeats, meant to magnify the glory of Roman arms, has rather the effect of undermining confidence in their authenticity in the regal period ( Livy, I.35.7-38,7; Dion.Hal., III.49-66, Alföldi,1963, p. 135-140).

In contrast to the shadowy king there is the vivid story of his coming to Rome from his birthplace, Tarquinia. Who does not remember the tale of Tarquin and his wife Tanaquil heading to Rome on their wagon, the swooping eagle, Tarquin's hat carried off by the bird, and Tanaquil, a woman skilled in divination, prophesying the greatness to come (Livy, I.34 etc.)? At the time Tarquin's name, we are told, was Lucomo: only later did he Latinize it to Lucius. The title Lucomo, the fundamental meaning of which from the Etruscan is diviner (and in Latin carrying a sinister undertone of affliction with the Evil Eye), of course belongs more properly to Tanaquil than to her husband. It is possible however, that neither she nor her spouse could lay claim to it. Tarquin was the son of a Greek, Demaratus the Corinthian, who removed to Tarquinia following the establishment of the Cypselid tyranny in his home city. Cicero guessed that the name Tarquin changed was not Etruscan but Greek: "Sic enim suum nomen ex Graeco nomine inflexerat" (Res.II.20.35). If I am not mistaken the Greek name was a nickname $\lambda \varepsilon \cup \kappa o ́ \kappa o \mu \circ \varsigma$ (the word is attested by Pollux, IV.139), "white-haired"(no doubt from premature aging rather than albinism). It stuck with him, but in the form Lucomos, shortened from Leucocomos, which the Romans easily misidentified as the Etruscan title (and name), Lucomo.

The tale of Tarquin and Tanaquil on their wagon, like the story of Tullia's exultant crushing of her father's dead body beneath the wheels of her chariot or the appearance of Tanaquil, probably in extreme old age, at the window on the death of a king named Tarquin, are elements, even when mixed with folklore, that are the real core of the history of regal Rome. Vivid and personal, but divorced from chronological reality, they have more to do with the women than with the men of the later regal age.

Tarquin "The White-Haired", remembered as the first of his family at Rome, was thus pressed into service for that nebulous early Tarquin King whose name had been forgotten. He was fitted with a praenomen which was enough like his Greek nickname to pass muster and provided with a career modeled on that of the king of the end of the sixth century. The annalists needed Tarquinius Priscus for another reason. The 240 or so years between the foundation of the city and the expulsion of the kings in 509 had to be accounted for. These 240 years represent 8 generations of 30 years. This span was divided, somewhat unevenly, between the four mythical kings (754-616) and the Tarquin dynasty (616-509). However, in that dynasty there was memory of only two kings of any substance, Servius Tullius and Lucius Tarquinius Superbus. The annalists would have been better chronologists had they acknowledged that two generations were missing.

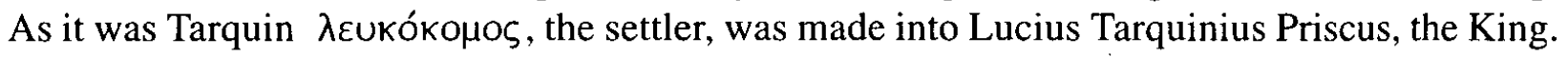

The chronological problem did not go unnoticed, even among the annalists. Lucius Calpurnius Piso Frugi, consul, censor and author of annals in the second century, pointed out the impossibility of a man who would have come to Rome already in 616 (traditional date) fathering a son, Lucius Tarquinius Superbus, who died in 495, when, as Piso calculated from various circumstances involved, he would have been at least 96 years old. Piso's solution was to consider 
Superbus the grandson rather than the son of Priscus, positing an unknown son of Priscus as his father, although Dionysius of Halicarnassus, through whom we learn of Piso's theory, refused to adopt an alternate solution which made Superbus the son of Priscus' second much younger wife (IV.7.2). This solution has had appeal among modern scholars (e.g. Gantz, 1975), but as has also been emphasized (de Cazanove, 1988) Piso's correction does not make any more credible the lenghts of the reigns in the Tarquin dynasty, 37 years for Tarquinius Priscus, 44 years for Servius Tullius, and 25 years before the revolution of 509 for Tarquinius Superbus. ${ }^{1}$

The second king in the Tarquinian succession, Servius Tullius, cannot be dismissed as a fiction, although much about him is uncertain (R.Thomsen, 1980). He bears a good Roman name and the story of his servile origins can only have to do with the possible descent from a slave of King Tullus Hostilius, thus the formation Tullius. Had he himself been attached to the household of Tarquinius Priscus his name would have reflected the fact. He is part of the Tarquin succession, therefore, only if we believe the story that his rise to power was favored by queen Tanaquil (and not necessarily the wife of old Tarquin "The White-Haired"). He was, however, equated by Etruscan scholarship with another of the figures shown in the François Tomb, Mastarna. This fascinating glimpse into Etruscan historiography is given in the speech of the Emperor Claudius concerning the admission of residents of Transalpine Gaul to the Roman Senate (CIL, XIII, 1688). Citing Etruscan sources, Claudius refers to the story that Mastarna, who reigned as Servius Tullius, gathered the remains of Caeles Vibenna's army, brought them to Rome and settled them on the Caelian hill. Part of the Etruscan story, in which Caeles liberates Mastarna, is shown in the François Tomb. Caeles Vibenna and his connection with the Caelian was also known to Tacitus (Ann.IV.65). Varro mentions him (L.L.V.46), and Verrius Flaccus seems to have said that Caeles and his brother aided a King Tarquin (Festus, p.355M). But was Mastarna really Servius Tullius, involving another name change and this one more drastic than the alteration of Lucomo to Lucius? We have no precise idea of the age of the Etruscan writers whose views were repeated by the Emperor. But it is unlike that they are earlier than the Roman annalists. That this was the case is shown by the fact that they knew of the Roman Servius Tullius and wanted to reconcile Etruscan history with what had become the standard Roman version of persons and events. Nevetheless, it is also apparent that the Etruscans were aware not only of Gnaeus Tarquinius, King of Rome, but of the condottiere Mastarna who had also played a major role in Rome of the Tarquin Period.

In the preceding we have examined three important persons of early Rome. The first is Tarquinius $\lambda \varepsilon \cup к o ́$ ко $\mu$ os. He came to Rome and settled there with his wife Tanaquil. There is no reason to believe that the annalistic reconstruction of early Roman history in which this man attained kingship. Mastarna is a different matter. Etruscan history knew him as a Roman king, although it reconciled its tradition with the Roman annalists by equating him with Servius Tullius. Finally Gnaeus Tarquinius is surely a king of Rome.

If the struggles of the Etruscan and Roman heroes in the François Tomb form a single episode, then the relative age of Mastarna and Ganeus Tarquinius is clear. The latter is an older and bearded man. But even if these scenes do not maintain a unity of time and place, the suggestion is the same, Gnaeus Tarquinius is older than Mastarna. He is likely to have been the son of Tarquinius $\lambda \varepsilon \cup$ кókouos. Since Servius Tullius and Lucius Tarquinius Superbus appear to be the last two kings of Rome, Gnaeus Tarquinius and Mastarna, whose relative order is established by artistic convention, must precede them. The following sequence of Roman rulers thus takes shape:

Gnaeus Tarquinius

Mastarna

Servius Tullius

Lucius Tarquinius Superbus. 
The Etruscan tradition, transmitted to us by paintings of the François Tomb, preserves the names of rulers of Rome in the early sixth century who had disappeared from the standard history of Rome. There are now four generations represented. But we should not take too much pride in solving the chronological problem first posed by Piso Frugi. The history of Rome of this period was too fluid, filled with warlords, intrigue, assassination, rape and revenge to permit us to think that we have recovered the names of all of the protagonists or of all those who may, at one time or another, have called themselves a king. What, for instance, was the sequel of Marcus Camillus assassination of Gnaeus Tarquinius? Was he some morning star Brutus who narrowly failed in setting up a republic? Or was he a would be king himself? We shall never know. Just as we shall never know how close Caeles and Aulus Vibenna may have come to the throne, or whether for some periods in the sixth century there was no king at Rome. An Aulus Vibenna dedicated a pottery vessel of the early to mid sixth century at Veii and there is every likelihood that he and the Aulus Vibenna of Roman history are one and the same (fig.4). And in the final analysis the real meaning of the word "rex" in this period is hidden, except that it implied priestly functions and that one or more of its holders made the word, in a political sense, hated by the Romans for the rest of their history.

\section{Notes}

1 - It has been further argued, de Cazanove 1988, that the correction also introduces confusion into the genealogy of the Tarquins, which includes the branches that through Tarquinius Priscus' brother Arruns produced the line leading to Collatinus, remembered both for his role in the drama of Lucretia and as consul in the first year of the Republic and that through Priscus' daughter led to Lucius Junius Brutus, founder of the Republic. In both these branches, as well as in the main family, a missing generation must be inserted. I feel, however, that the genealogy of the Tarquins, as reconstructed by the annalists, cannot be trusted very far. de Casanove also wishes to lower the date of Tarquinius Priscus' arrival at Rome to about 570, thus following a "low" date for the Cypselid tyranny at Corinth, which must be synchronized with the departure of Demaratus.

\section{Bibliographical note:}

For early Rome in general one may consult T.J. Cornell, The Beginnings of Rome, London, Routledge, 1995; A. Momigliano and A. Schiavone, eds., Storia di Roma I, Einaudi, Torino, 1988; F.W. Walbank, A.E. Astin, M.W.Friederiksen and R.M. Olgivey, eds., The Cambridge Ancient History, ed.2, vol VII, Univ. Press, Cambridge, 1989, all with exhaustive bibliography. For the François Tomb, G. Körte, "Wandgemälde von Vulci als Document zur römischen Königsgeschichte", Jahrbuch des Deutschen Archäologischen Instituts 12. 1897: 57-80; F. Masserschmidt and A. von Gerkan, Nekropolen von Vulci (Jahrbuch des Deutschen Archäologischen Instituts, Ergänzungsheft 12), de Gruyter, Berlin, 1930: 62-163; F. Buranelli, La Tomba François di Vulci (20 marzo-17 maggio 1987) Quasar, Rome, 1987, with recent bibliography.

\section{Bibliography}

ALFÖLDI, A. Early Rome and the Latins. Ann Arbor: University of Michigan Press, 1963.

BONFANTE, L. Etruscan Dress. Baltimore: John Hopkins Univ. Press, 1975.

CORNELL, T.J. The Beginnings of Rome. London: Routledge, 1995. 
DE CAZANOVE, O. La chronologie des Bacchiades et celle des rois étrusques de Rome. Mélanges de l'École Française de Rome, 100, p. 615-648, 1988.

GANTZ, T.N. The Tarquin Dynasty. Historia 24, p. 539-545,1975.

POUCET, J. Les origines de Rome. Bruxelles: Facultés Universitaires Saint-Louis, 1985.

THOMSEN, R. King Servius Tullius: a historical synthesis. Copenhagen: Gyldendalsk, 1980.

HOLLOWAY, R. R. Cneve Tarchunies Rumach. Classica, São Paulo, 7/8: 101-110, 1994/1995.

ABSTRACT: The object of this paper is to view what the painted decoration from the François Tomb says about the Roman kings of the sixth century B.C. as independent evidence rather than as a gloss on the Roman history as written by the annalists of the second and first centuries B.C.

KEY WORDS: François Tomb; Roman kings; wall paintings. 


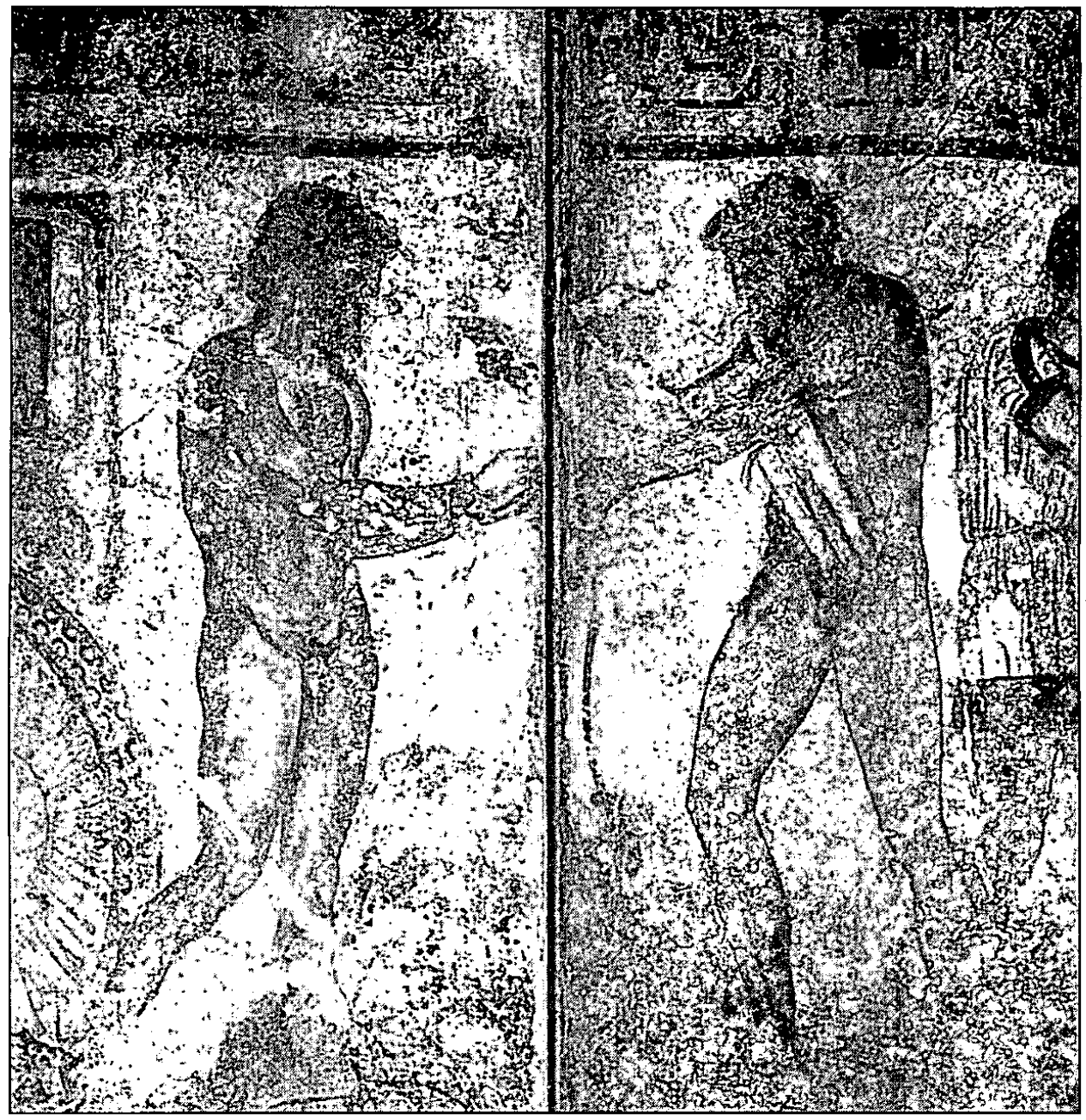

Figural: François Tomb, Vulci. Mastarna freeing Caeles Vibenna. After La Tombe François di Vulci. 


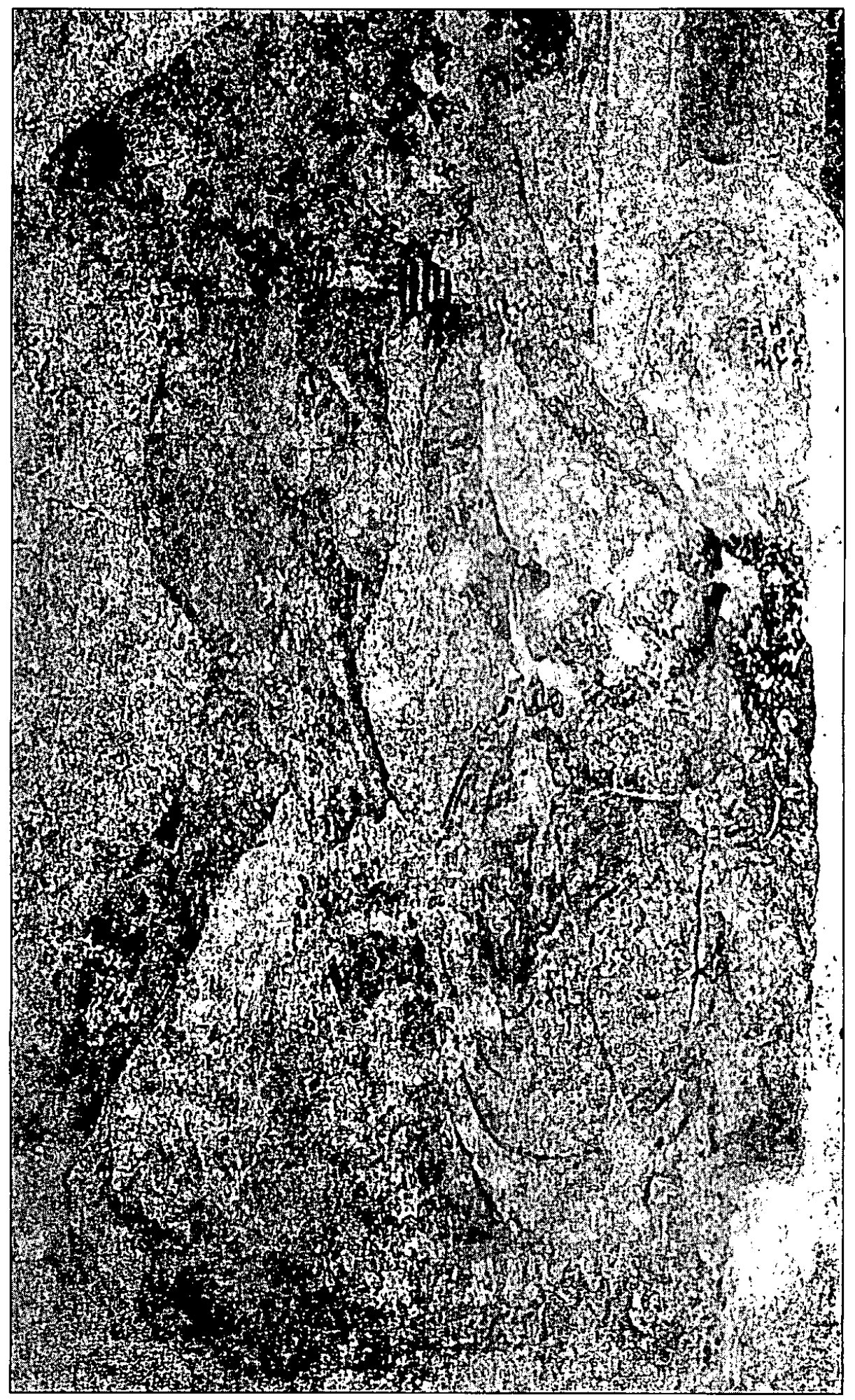

Figura 2: François Tomb, Vulci. Marcus Camillus and Ganeus Tarquinius of Rome. After La Tomba François di Vulci. 


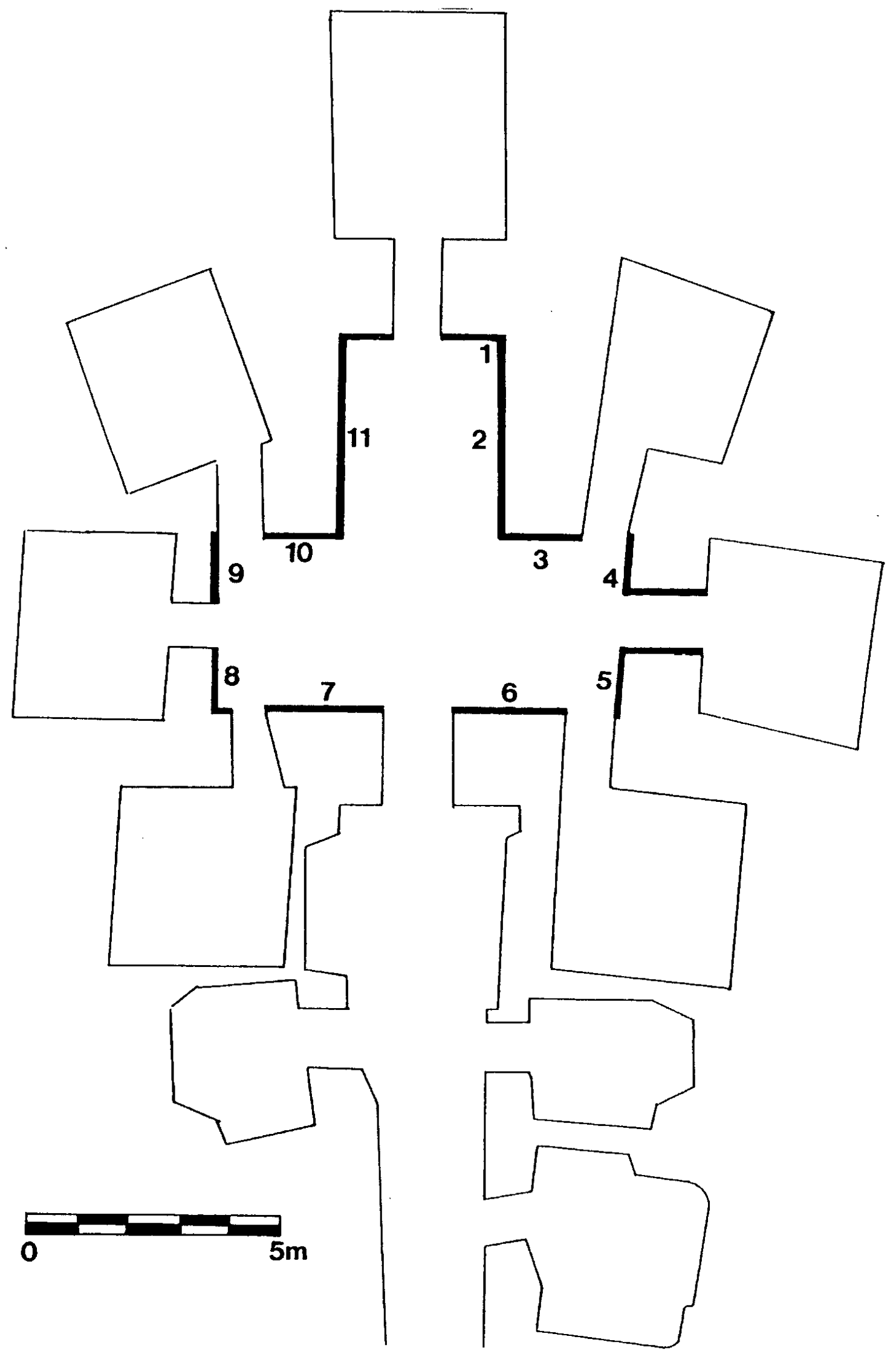

Figura 3: Plan of the François Tomb at Vulci. 1) Mastarna and Caeles Vibenna; 2) Other pairs of Etruscan antagonists; 3) Marcus Camillus and Ganeus Tarquinius; 4) Vel Saties; 5) Thanchvil Verati (Tanaquil); 6) Sisyphos and Amphiaraos; 7) Ajax and Kassandra; 


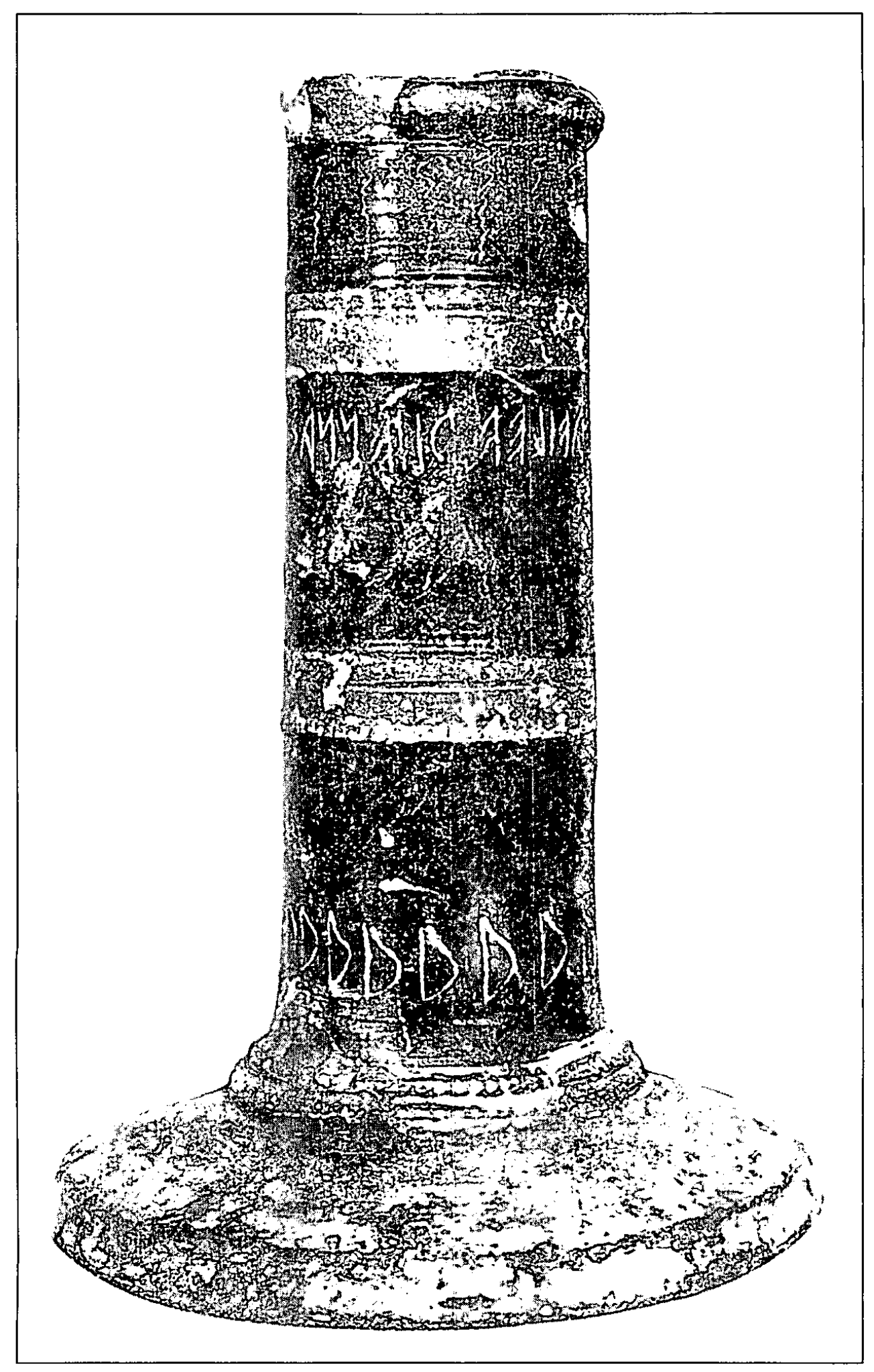

Figura 4: Vase dedicated by Aulus Vibenna at Veii. After Storia di Roma, I. 